\title{
Marriage and divorce in Malachi 2:10-16: An ethical reading of the abomination to Yahweh for faith communities
}

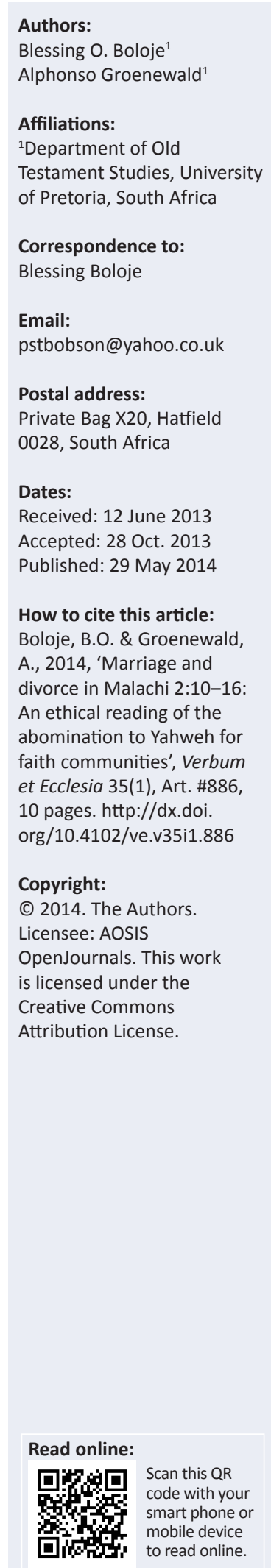

The family is the bedrock that forms the indispensable foundation for discipleship. It was instituted by the Creator as his primary setting for human development and nurture (Gn 2:18-25; Ps 68:5, 6). Thus the crisis involving marriage and the family is indeed a cultural crisis of the first order. Social life quite simply cannot function effectively without the family. Whilst according to Flowers and Flowers: 'Christian families face the challenge of understanding and stretching toward the divine design for life and relationships, even as they dwell in a world where hard reality find us far short of God's plan for family living', this article demonstrates that Malachi's prophetic oracle (2:10-16) is an urgent motivation and challenge to Yahweh's people in faith communities to be living embodiment of the ideals of fidelity, commitment and steadfastness. In honouring these values and ideals, the article further challenges Yahweh's faith communities to seek concrete ways of affirming, strengthening, empowering and supporting persons and families in their efforts to live in faithfulness to the values they recognise and esteem.

\section{Introduction}

The family is the bedrock that forms the indispensable foundation for discipleship. In light of its fundamental place, namely 'the primary place where the capacity for love and intimacy with God and other human beings is developed and where spiritual values are extended across generations' (Flowers \& Flowers 2001:85), the family thus forms the indispensable foundation for discipleshipmaking process of the church in the larger human society ${ }^{1}$ (Mt 28:19; Jn 8:31; 13:35).

If one takes as a basic assumption that the biblical text is the authoritative word for the church, the appropriate setting within which to do ethical readings will be the ecclesial community. In this regard, ethics cannot simply be an academic exercise removed from the life of the church. Theology and ethics are inseparable in the Hebrew Bible or Old Testament. Walter (2007) notes that ethics in the Old Testament is primarily theological ethics because the Old Testament is a theological book rooted in historical realities of the Hebrews:

God is its chief character, its major actor, the chief person about whom statements of character and agency are made. Critical thoughts about the text are bound to include ethical reflection on the conduct of this character as much as on that of others. (p. 1)

In the Old Testament, ethics is thus fundamentally theological. At every point, it is related to God, namely his character, his will, his actions and his purpose. Thus one can say that Old Testament ethics are God-centred in origin, in history, in content and in motive (Wright 1983:21). Old Testament ethics focuses on Israel's perspective of good behaviour, the possibilities it offers as well as its justification (Groenewald 2009:421). Thus the best way to appreciate and apply the ethics of the Old Testament or Hebrew Scriptures is to attempt:

to put ourselves in Israel's position and understand how they perceived and experienced their relationship with Yahweh, the God of Israel; and how that experience affected their ethical ideals and practical living as a community. (Wright 2004:17)

The ethics of the Old Testament or Hebrew Bible is rooted on insight into the character of God. Yahweh, the God who behaves ethically, also demands ethical behaviour from his worshippers. Obedience and commitment to the declared will of God is a strong justification for ethical obligation in the books of the Old Testament or Hebrew Bible. The justification for ethical deeds is furthermore rooted in the festive, cultic community. The scribes writing the biblical books regarded 'the good' as that 'way of life' (Ps 16:11), which God instructed and demanded of human

1.This article understands the term 'church' to mean the people of God that are built together into a spiritual building for God's habitation (Eph 2:20-22). It includes the company of believers in Christ through all ages, a company which is distinct from the world by virtue of its calling from and separation unto God (Eph 1:22; 3:10, 21; 5:25-32). The expressions 'ecclesia community', 'Yahweh's faith community' and 'Christian community' are used interchangeably in this article. 
beings. Thus, ethical behaviour becomes visible when it is accomplished through experience and reason and mediated through teaching (Groenewald 2009:430-431). What characterised moral action in the ancient world, particularly of the eastern Mediterranean, was a synthetic perspective of life. It assumes a correspondence between people's experience of life and their deeds (Levin 2006:46; Otto 2004:84). Here, the interrelationship between sapiential thought and the ethics of the Old Testament or Hebrew Bible becomes very clear 'as it includes the notion of order in human life, that is, that moral conduct in accordance with ethical rules should lead to a good life' (Groenewald 2011:1).

It has, however, been noted that the ethical rules of the wisdom literature are very distinct from those of the law codes. Its (wisdom literature's) literary history is basically connected to the theological discourse about the legitimisation of these rules and the consequences of ethical conduct. At the dawn of the 'post-exilic period, wisdom in Israel, in contrast with, for example, wisdom thought in Egypt and Mesopotamia, went through a significant process of theologisation (Groenewald 2011:1). Whilst the core of Hebrew ethics should rather be sought in the idealistic framework and structure which legitimises its values and norms (Groenewald 2009:422), ${ }^{2}$ the theological traditions that undergirded prophetic ethics in the Old Testament or Hebrew Bible during the first threequarters of the 20th century scholarship are considered to be primarily the covenant, law, clan wisdom and creation. However, Carroll (2012) argues to the contrary:

The ethical message of the prophets cannot be limited to any theological tradition ... The prophets would have moved and spoken within a moral universe into which multiple range of theological emphasis fed. (pp. 186-187)

\section{In his survey, Carroll (2012) demonstrates that:}

\begin{abstract}
... the prophetic literature is a rich resource for ethics, whether the goal is to describe the ethical thinking and moral behaviour of ancient Israel (or of the authors of the books), or the purpose is to probe the Prophetic Books for contemporary ethical guidance. (p. 191)
\end{abstract}

The meaning of Malachi for Christianity or the Christian tradition must be found, therefore, within the limitations of the text's basic orientation. Since Malachi was about the failure of both the priests and the people to worship God, the Christian meaning of the text cannot depart from these themes into, say, flights of allegory. One must attempt to discover what exegetes thought the text meant as part of the Christian Scripture or canon for their community (O'Keefe 1996:142-143). Malachi as conscience of his people was skilful and creative in adapting the older prophetic traditions to the advantage of his religious, economic and socio-cultural context. To his generation, the oracles of Malachi, along with the events they:

2.Groenewald (2011:1) notes that, "with regard to this idealistic structure of Hebrew ethics, the focus is primarily on the Pentateuch as the main source for its structure' ethics, the focus is primarily on the Pentateuch as the main source for its structure' (see Jensen 2006.20-24; Oto 2007:26; cf. Otto 1995:162). 'The legal collections in the Torah form one of the pible], specifically the system of legal and ethical rules which we find in the ... Covenan Code (Ex 20:22-23:33), Deuteronomic Law (Dt 12-26) and the Holiness Code (Lv 17-26)' (Groenewald 2011:1) witnessed threw into question all the covenantal commitments on which the people had staked their security and that were supposed to guarantee the endurance of the tripartite covenantal triangle involving Yahweh, Israel, and the land of Canaan. (Block 2006:35)

Malachi confronts a population given to religious cynicism and political scepticism. Morality seemed to have been totally forgotten. The weakening of the religious life in Malachi's day was shown clearly, and it had grave social implications. Perversity at the place of worship had resulted in perverseness on the part of those who come to worship. Wrong views of God and false forms of worship inevitably lead to fractured social relationships. Divorce (Ml 2:13-16) and adultery (3:5) were so common that the total destruction of Jewish families seemed almost imminent. Yahweh's established system of ordered community was subverted (Barton 1995:90-91). Since Malachi consistently roots his narrative of marriage and family within the framework of a community that shares an essential relationship and fellowship based on a common father and creator (Schuller 1996:866), this article intends to demonstrate that Malachi's prophetic ethics as demonstrated in his oracle (2:10-16) is an urgent motivation and challenge to Yahweh's people in faith communities to be living embodiment of the ideals of fidelity, commitment and steadfastness. In honouring these values and ideals, the article further challenges Yahweh's faith communities to seek concrete ways of affirming, strengthening, empowering and supporting persons and families in their efforts to live in faithfulness to the values they recognise and esteem. As a background, the article examines the literary form of the oracle and its ethical dimensions, and it then focuses these directly on Yahweh's people in faith communities.

\section{Literary form of Malachi 2:10-16}

Malachi (mal'ākhî) in the Hebrew Bible simply means 'my messenger'. The identification of the form mal'ākhî has constituted research problems, and defensible positions have emerged from several scholarly debates. ${ }^{3}$ On the one hand, Malachi is considered to be a proper name of the writer of the oracles, and on the other hand, the name is seen as a title or appellative for the anonymous person responsible for the compilation of the book (Hill 1998:15). According to Hill (1998:18), mal'ākĥे is indeed a person of considerable personal piety, grasping the import of Yahweh's holiness and the seriousness of personal and community sin before God (cf. 2:17-3:4, 6-7, 13-19). His staunch convictions against malpractices such as mixed marriages and unfaithfulness to Yahweh (2:10-12), easy divorce (2:13-16) and social injustice (3:5) were a throwback to the days of pre-exilic prophets.

That mal'ākhî was a person of integrity and courage is evidenced in his bold upbraiding of the influential priestly class and social elite (cf. $1: 1-14 ; 2: 1-4 ; 3: 2-4$ ). At the same time, he shows evidences of great compassion for his people in the words of assurance and encouragement that open and

3.The various controversies about the title mal'äkhî that have constituted research problems and from which defensible positions have emerged in several scholarly debates have been dealt with in the first author's doctoral thesis which is still in progress. 
close his message. He demonstrates considerable continuity with the covenantal message of earlier Hebrew prophets. He understood clearly the primacy of the internal attitude and motives of the heart in contrast to the external form of ritualism (1:9-13; 2:2-3; 3:16-18). He recognised that the blessing and curse of God were rooted in personal and corporate obedience or disobedience to the stipulations of Israel's covenant charter (3:16-21). Most importantly, he understood that the demands of covenant included a righteous ethic, a code of behaviour consistent with the nature and character of God, the covenant maker (3:5-7; cf. Zch 7:8-12). It is therefore in this light that Weiser (1961:277, cited in Hill 1998:18) concludes that 'the book of Malachi breathes the spirit of an original, genuinely prophetic personality'. Although the book of Malachi is not specifically dated, internal evidence suggests that it originated in the post-exilic period, probably in the 5th century BCE (Chisholm 2002:447).

Whilst it is important for readers to know the primary message of Malachi by way of identifying the literary genre, it is also important to determine how the author has arranged the message of the book in order to highlight its central concerns. The Christian Old Testament ends with the words of the prophet Malachi, a structure to the book inherited basically from the translators of the Greek translation of the scriptures, the Septuagint (LXX). Written after the return from Babylonian exile, Malachi describes the continuing unfaithfulness of the people of God. This ending also looks to the future but a different kind of future. The book concludes with warnings about impending judgment and the announcement of the coming of the prophet Elijah (Jackson 2004:41). Perhaps because of the people's disillusionment and contempt for their covenant with God, Malachi uses a somewhat unique structure in trying to make God's point with the people. Although it was occasionally used by other prophets, no one else uses it to the extent that he does. Whatever labels one gives to the oracles of Malachi-discussion, dialogue or disputation - it has become almost axiomatic in Malachi studies that the book comprises six speeches, ${ }^{4}$ a superscription and two appendices (4:4

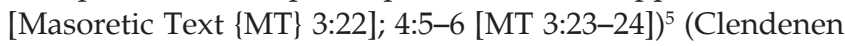
2004:227; Hill 1998:26).

With respect to the form of the prophecy, it has been noted that Malachi has a style that is unique amongst the Old Testament prophetic books (Clendenen 2004:218). Many a scholar has assessed the literary features of Malachi, and the discussions have focused on how best to describe the method Malachi uses to communicate with Israel. It may be described as 'prophetic disputation' (Murray 1987:110), 'confrontational dialogue' (Hendrix 1987:465), 'covenant

4. Hill (1998:26), following other interpreters, "identified six such disputation speeches in Malachi: (1) 1:2-5, (2) 1:6-2:9, (3) 2:10-16 (excluding vv. 11-12 as a late addition), (4) 2:17-3:5, (5) 3:6-12, and (6) 3:13-21 (Eng., 4:3; the last three verse of the canonical book, 4:4-6 in English, are excluded as a later addition)' (Clendenen 2003:1).

5.Although some would not agree (Assis 2011:208-209; Clendenen 2004:455; Floyd 2000:568-569; Glazier-McDonald 1987:243-245; Koorevaar 2010:75; Stuart 1998:1391; Verhoef 1987:337-338), the conclusion of the book of Malachi in 4:4-6 (Mt 3:22-24) is widely considered to be a later redactional addition (or additions) to (Mt 3:22-24) is widely considered to be a later redactional addition (or additions) to Mallachi 3:13-21 and, for that matter, lawsuit' (O’Brien 1990:63), ${ }^{6}$ sermonic (Pierce 1984:285) or oracular, but its frequent use of quotations, rhetorical questions (see Merrill 1994:380) and polemical argument gives it a peculiar character (Clendenen 2004:218). Again, 'catechetical format' has also been suggested to capture the questioning approach used in Malachi, a technique found also in Haggai (Braun 1977:299). ${ }^{7}$ The division of the book's message into six smaller sections (Pierce 1984:282) has given rise to the classification of the book as comprising of disputation speeches (Clendenen 2004:218; Petersen 1995:29; Redditt 2000:849). Most of these sections are regarded as having a three-part form - an established proposition, the respondent's objection and the key and concluding element - which may itself be made up of smaller elements, that is, oracle of salvation, threat or admonition. In Malachi, Clendenen (2004:219) identifies six disputation speeches:

(1) 1:2-5, (2) 1:6-2:9, (3) 2:10-16 (excuding vv. 11-12 as a later addition), (4) 2:17-3:5, (5) 3:6-12, and (6) 3:13-21 (Eng., 4:3; the last three verses of the canonical book, 4:4-6 in English, are excluded as a later addition). (Clendenen 2003:1)

This third dispute ( $\mathrm{Ml} 2: 10-16)$ is considered as 'the most problematic in Malachi' (Schuller 1996:864) and 'a crux interpretum' (Kealy 2009:235). 'The literary form of the oracle is similar to that of other oracles following the questionanswer-refutation pattern with the exception, as with the fifth oracle, that it is the prophet [or prophetic figure] who begins the oracle and not Yahweh himself. The oracle is addressed to the [greater restoration] community of Yehud' (Wickham 2009:145), leaders, priests and people, making the 'one' people of Yahweh. The purpose of the oracle is both didactic (correct instruction on the topics of marriage and divorce countering the spurious tutelage of the Levitical priests, 2:1-9) and admonitory (a timely warning for circumspect selfexamination as a prelude to the prophet's final indictment of Yehud in 2:17-3:5 and as a preparation for the prophet's call to repentance in 3:7) (Hill 1998:223-224). Whilst some scholars have argued that the passage refers to the condemnation of idolatry (Petersen 1995:198-200; Zehnder 2003:229-230), ${ }^{8}$ most contend that Malachi 2:10-16 is concerned with human intermarriage in the postexilic community (Dumbrell 1976:42-52; Hugenberger 1994:339; O'Brien 1995:57-79, cited in O'Brien 1996:244; Verhoef 1987:270). Such scholars and commentators interpret 'daughter of another god' (2:11) as a direct reference to unfaithfulness to Yahweh via worshipping of other gods. O’Brien (1996) notes:

Such an interpretation is derived from (1) understanding 'daughter of a foreign god' as a foreign woman involved in-and enticing others to-idolatry; and (2) relating' sending'(most often

6. In order to account for the use of covenant terminology that many have been used in the book, she analyses the book as comprising of five 'accusations' (1:6-29; $2: 10-16 ; 2: 17-3: 5 ; 3: 6-12 ; 3: 13-21)$ in addition to a 'prologue' $(1: 2-5)$, a 'final admonition' (3:22) as well as a 'final ultimatum' (3:23-24).

7.Boda (2000:299-300) notes: 'The interrogative mood engages the audience in a powerful way, forcing them to reflect on the message in a deeper measure than in mere pronouncements. It is used by Haggai both to bring judgement $(1: 4,9$; $2: 12-13,19)$ and to express sympathy $(2: 3)$.' See also Craig $(1996: 244)$ and Pierce
$(1984: 277)$ who have exploited the question style for redactional ends, suggesting that they point to the unity of Haggai-Zechariah-Malachi.

8.Petersen (1995:198-200), for instance, emends 2:11b to read: 'Judah has profaned the very holiness of Yahweh. He loves Asherah; he has married the daughter of a foreign god.' 
translated' divorce') and 'the wife of your youth' to the practice of a Judean man divorcing his original (Judean) wife in order to marry a more affluent foreign woman. According to this understanding, Malachi describes the problem to which Ezra/ Nehemiah's abolition of mixed marriages in the restoration community later provides the answer; it is the most common argument for situating the book immediately prior to Ezra's reforms. (p. 244)

Intermarriage and divorce are supercilious and reprehensible misdeeds before Yahweh, an affront to the essence of the covenant relationship socially and religiously. The transgression and/or violation defiled the people of Yehud, polluted their worship of God and made a sacrilege of Yahweh himself (Hill 1998:223). This confrontation involves the rejection of the people's offerings (2:3), implying that Yahweh sees through the insincerity of the ritual mourning precisely because Yahweh has seen it before (2:14) (Nogalski 2011:1042). The textual references to altar, temple and its personnel as well as inter-textual links all bear witness to ritual violation and contempt.

\section{Ethical dimensions in Malachi 2:10-16}

Verses 10-16 focus on the horizontal aspect of Judah's unfaithfulness - the breaking of marriage covenants. The accusations (Stuart 1998:1329):

are based in part on the relationship shared by the people of Israel as the offspring and creatures of the one God [2:10a]. Realizing that God brought them into existence as a united whole in a covenant relationship to himself should have produced faithfulness not only to him, but also to one another. (Clendenen 2003:9)

Thus, to motivate their obedience, Malachi reminded them of their spiritual and covenant unity by the use of such repeated ideas as unfaithfulness (bāghadh) and one ('ehāadh), which appear between five and four times respectively. In it, Yahweh is called the one father and creator of everyone: hălô' 'ābh 'ehādh lekhullānû hălô' 'ēl 'ehādh berā'ānû (2:10a). Here in Malachi 2:10a, the Lord's fatherhood is used to rebuke unfaithfulness. This section examines the peoples' unfaithfulness along the following lines: mixed marriages, unfaithfulness to God (corrupted worship) and divorce.

\section{Malpractices of mixed marriages and unfaithfulness to God: Malachi 2:10b-12}

The second question in Malachi 2:10b, madhdhü $\hat{u}^{a}$ nibhgadh 'îsh $b^{e}$ 'āhîw lehallēl berîth 'ăbhōthên û [Why - if we have one father - are we dealing treacherously each against his brother so as to profane the covenant of our fathers?], introduces an unusual communal self accusation. The interrogative madhdh $\hat{u}^{a}$ introduces the accusation against Judah for their unfaithfulness against fellow covenant partners. Such unfaithfulness is considered to profane or violate Israel's covenant with God just as the priests' attitude was violating the Levitical covenant (2:8). Thus the violation of the social responsibility of the covenant, that is, failure to love one's brother amounts to violation of the religious responsibility, that is, failure to love God (Clendenen 2004:326).

The verb $b \bar{a} g h a d h^{9}$ [to act faithlessly, deal faithlessly, be treacherous, cheat, break one's promise] denotes human instability in contrast to the stability of God's covenant as well as treacherousness in the context of marriage (Pohlig 1998:94). It is used of a man who does not honour an agreement or commits adultery or breaks a covenant or some other ordinance given by God (Botterweck \& Ringgren 1974:470). It is most likely that Malachi carefully chose this term as his inspired thinking shaped the wording of Malachi 2:10. According to him, not only were the men of Judah guilty of committing acts of treachery such as betrayal of the marriage covenant, but their attitude involved violation and invariably a betrayal of the covenant with God, identified here as berith 'ăbhōthênû [covenant of our fathers]. ${ }^{10}$ The indictment of profaning the covenant is expressed by the use of the verb hălal [to desecrate, break, violate, defile, despise] (Brown, Driver \& Briggs 1997:320). The verb occurs in Malachi 1:12 and 2:11 with the respective ideas of profaning Yahweh's name and desecrating the sanctuary. In other words, as Clendenen (2004) puts it:

to profane a covenant would be to disregard it or treat it with contempt by violating it. Since it was a covenant made not only before God but with God, profaning it involved the most serious repudiation of faith. (p. 328)

Verse 11 communicates the fact that, in Malachi's day, the people of Judah were committing widespread, serious covenant violations and thus profaned Israel's relationship with her God. These violations entailed intermarriage as portrayed in the Old Testament. ${ }^{11}$ In Malachi 2:11a, the accusation, bāghdha $\bar{a}^{h} y^{e} h \hat{u} d h \bar{a}^{h}$ [Judah has been faithless or has dealt treacherously] is elaborated by the coordinated

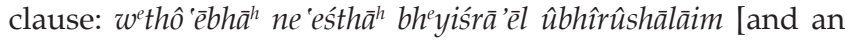
abomination has been committed in Israel and in Jerusalem]. That it damaged Israel's favour with Yahweh is expressed in the reference to harming Yahweh's sanctuary which he loves (kî hillēl y'hûdhāh qōdhesh yhwh ['ädhōnāy] 'ăsher 'āhēbh),

9.The verb bäghadh and its related words occurs most often in reference to Israel's covenant with Yahweh ( $\mathrm{Ml} 2: 11$ ), usually in contrast to unfaithfulness. In Hosea 6:7, it is used synonymously with covenant transgression. The word connotes shattered hopes and often suggests deceit (Jr 9:2) and disaster (Pr 11:3, 6; Is 24:16; 33:1). These ideas can best be applied to acts of marital unfaithfulness such as adultery, desertion and divorce (cf. Ex 31:8; Pr 23:28; Jr 3:8, 11, 20; Hs 5:7) (Clendenen 2004:327).

10.The reference could be to God's covenant with Abraham, Isaac and Jacob, the patriarchal or Abrahamic covenant. But the accusation of unfaithfulness to one's brother fits the context of the Mosaic covenant, which constituted Israel as a nation. See discussion on the covenant of our fathers in chapter four of the thesis. See Petersen (1995:197) and Verhoef (1987:267).

11.Intermarriage as defined by the Old Testament is marriage between an Israelite man and a non-Israelite woman. The opposite case is seldom more than a theoretical possibility (see Tiemeyer 2006:177-193). Whilst a literal interpretation of Malachi 2:10-16 has been proposed (Hugenberger 1994:339), others argue that Malachi's language should be interpreted figuratively (O'Brien 1996:249; Petersen 1995:198-200). O'Brien (1996:244) notes that, though several commentators 1995:198-200). O'Brien (1996:244) notes that, though several commentators have argued that the passage refers to idolatry, most contend that Malach $2: 10-16$ is concerned with human intermarriage in the postexilic community The interpretation here is in line with the majority of scholars who understan This position is clearly articulated from the evidence in the books of Ezra and Nehemiah (Ezr 9:1-2; Neh 13:15-17), a problem that continued in the postexilic community, even amongst the priests. 
and that religious intermarriage was the problem is clearly reflected in the final clause: $\hat{u} b h \bar{a}$ 'al bath-'ēl nēkhār [and has married the daughter of a foreign god].

The term tô' $\bar{e} b h \bar{a}^{h}$ [abomination, something detestable] denotes in its primary sense something detestable in the cultic realm, that is, in respect to what is related to Israel's worship of Yahweh. Its secondary senses carry the idea of detestation into moral and then general senses (Pohlig 1998:97). The term was used to describe various immoralities, including those notable amongst the Canaanites, such as prostitution, child sacrifice, witchcraft, dishonesty, violence and the perversion of justice. ${ }^{12}$ Malachi's use of tô 'ēbha ${ }^{h}$ sends a signal that Judah's misdeeds are bringing her into the same kind of idolatry mentioned in Deuteronomy 18:9-13. In Deuteronomy 18, yiśrāe él is synonymous to $y^{e} h \hat{u} d h \bar{a}^{h}$ and refers to Yahweh's covenant people without any reference to the former northern kingdom (Pohlig 1998:99).

Locating the abomination in Jerusalem implies that the violation was committed even in the spiritual centre of the nation (the heart-centre of God's covenant people, their religious capital and the place of God's presence amongst his people), thereby desecrating 'the sanctuary the Lord loves' (qōdhesh yhwh) (Clendenen 2004:331). The phrase which seems to elaborate and motivate the accusation qödhesh yhwh [Yahweh's holiness which he loves] occurs only here and in Leviticus 19:8 where it refers to an offering that has been consecrated to Yahweh. Whilst qödhesh yhwh [the sanctuary the Lord loves $]^{13}$ in Malachi may probably refer to the newly built temple that Judah's attitude had defiled, a reasonable alternative is that it refers to God's people which was formed by Yahweh to be cherished by himself and which was therefore set apart for himself with the intended backward reference to his declaration of love for them in Malachi 1:2 (Clendenen 2004:333; Pohlig 1998:99; Stuart 1998:1332; Weyde 2000:230-234).

The interpretative crux is the clause $\hat{u} b h \bar{a}$ 'al bath-' $\bar{l} l$ nēkhār [and has married the daughter of a foreign god]. It is most likely that bath-'ēl nēkhār refers collectively to women outside the narrow bound of the community of faith, foreign pagans who worshipped a god other than Yahweh (Clendenen 2004:336). ${ }^{14}$ The probable motives that prompted this intermarriage could have been money or sex (Stuart 1998:1331-1333). According to Stuart (1998):

Money was probably the main motive. It came from the establishment of marriage ties with landed non-Israelites, who would favour their in-laws in business dealings in general and the granting of jobs in particular. Sex was probably less often

12.See passages such as Leviticus 18:22-30; Deuteronomy $12: 31 ; 18: 9-12 ; 22: 5$ 23:17-18; 1 Kings 14:24; 2 Kings 16:3; Proverbs 3:31-32; 6:16-19; Jeremiah 6:13 16; Ezekiel 18:5-13; 22:2-12; 33:25-16, 29, as well as Petersen (1995:198), O’Brien (1990:68), Glazier-McDonald (1987:77-90).

13.The Targum (Verhoef 1987:268f.) translates: 'because the house of Judah desecrated themselves, who have been sanctified by the Lord, and whom he loves.' Thus by intermarriage, the men of Judah profane Yahweh's people, whom he loves (Verhoef 1987:268f.).

14.Clendenen (2004:336-337) observes further that Judah's sin was simply literal marriage outside the community of faith. Whilst Malachi does not give any indication of how many were guilty of this treachery, the problem and the guilt could be described collectively as Judah's. dominant ... especially in those cases where a man had become tired of his first wife (2:14-16). Pagan practices allowed for women to be treated as sex objects ... (Num. 25; Hos. 4:6-14; Am. 2:7-8) and many Israelite men must have found it easier to marry outside their people and faith into pagan families who would not insist on monitoring their daughter's welfare in the home of her husband as Israelite families would. Pagan families would also tolerate marriages after divorce - marriages based on physical attraction ... (pp. 1332-1333)

Van der Woude (1986:66) suggests that '.. by marrying foreign women Judaeans tried to share in the privileges of the alien overlords'. In the same vein, Hugenberger (1994:103-104) adds:

In a world where property frequently was inalienable and where wealth and status were primarily in non-Israelite hands, the temptation for the retuned exiles to secure these through intermarriage must have been significant. (pp. 103-104)

The punishment for violating qödhesh yhwh [Yahweh's holiness which he loves] is the same as it is in Leviticus 19:8, namely, the sinner must be cut off from his people. Verse 12 is Malachi's prayer to Yahweh about excommunicating from the community of Yehud the man who marries a foreign woman ( $\hat{u} b h \bar{a}$ 'al bath-'ēl nēkhār). It is clear from the context that the expression lāîsh 'ăsher ya'ăśenna $\bar{a}^{h}$ [the man who does this] refers to anyone who is guilty of illicit divorce and remarriage (Wickham 2009).

The precise meaning of this curse is unclear. The curse is complicated by a phrase that consists of two coordinated participles, namely 'ér $w^{e} \bar{o} n e^{h}$ that are variously derived and translated to include everyone. ${ }^{15}$ In line with probable intention of those supporting the illicit marriage (witness and answerer), whether in a legal or cultic sense, Hill (1998:235) argues that '... the idiom probably has legal connotations, perhaps related to the juridical procedure requiring two witnesses ...' The implication is that the '... culpability extends beyond those who have divorced their Hebrew wives and remarried non-Hebrews', that is, to the '... aiders and abettors of those in Yehud practicing intermarriage with non Hebrews'. Thus, the text refers to the act of illicit marriage, and it involves all the people supporting the legal contraction, including witnesses, priests and the grooms. The term yakhrēth from the verb kārath ${ }^{16}$ [to cut off, remove, deprive] (Brown et al. 1997:503; Harris, Archer \& Waltke 1980:1048) describes radical removal or eradication, and the phrase mē'ohŏle ya 'ăqōbh [from the tents of Jacob] echoes the penalty formula found mainly in the Pentateuch (Gn 17:14; Ex 12:15, 19; 31:14; Lv 7:20, 21, 27) (Clendenen 2004:340).

15.Amongst the various derivations and translations are: "him that waketh and him that answereth', 'he that calls and he that makes reply', 'the master and the scholar', 'the aroused and the lover', 'protector and appealer', 'protector and oppressor', 'whether nomads or settlers', 'hostile witness and defending counsel', 'anyone who gives testimony on behalf of the guilty', 'any to witness or answer' 'witness and advocate', 'root and branch', 'nakedness and improper cohabitation' (Hill 1998:234-235; O’Brien 1990:69, 2004:337-338; Petersen 1995:194-195; Pohlig 1998:100; Stuart 1998:1334; Weyde 2000:241-246).

16.The term as defined by Jewish exegesis includes the ideas: (1) childlessness and premature death, (2) death before age sixty, (3) death before age fifty-two, (4) extirpation, that is, termination of one's line of descent, or (5) loss of life in the hereafter, that is, exclusion from 'resting' with one's father or from being 'gathered' to one's people after death (e.g. Gn 15:15; 47:30; 49:29; Nm 20:24; Dt 31:16; to one's people after death (e.g. Gn 15:15; 47:30; 49:29; Nm 20:24; Dt 31:16;
Jdg 2:10; $2 \mathrm{Sm} \mathrm{7:12),} \mathrm{(6)} \mathrm{excommunication} \mathrm{or} \mathrm{(7)} \mathrm{human} \mathrm{execution} \mathrm{(Clendenen}$ 2004:340). 
Malachi thus concludes verse 12 with the words ûmaghghîsh minhāa lyhwh (la'dhōnāy) tsebhā'ôth [though he brings offering to the Lord of hosts]. The message of the noun clause in this verse is that the evildoer brings an offering to Yahweh in vain; his offering is useless, for he is violating the law by intermarriage.${ }^{17}$ The negative evaluation of the offering of the evildoer here in Malachi 2:12b reminds one of the rejection of the offering of the priests in Malachi 1:10 and 13 where references to their offering are made using the same term $\operatorname{minh} \bar{a}^{h}$ [general term for offering of any kind] as in Malachi 2:12b (Weyde 2000:249). This is by implication the language of rejection of the cult.

\section{Divorce of Jewish wives by Jewish men: Malachi 2:13-16}

Whilst Malachi 2:10b-12 focuses attention on instances of Judah's violation of their covenant with God, involving marriage to pagan women, Malachi 2:13-16 ${ }^{18}$ concentrates on violations of the marriage covenant (Zehnder 2003:224-259). It may simply be that both intermarriage and divorce are examples of unfaithfulness. By way of maintaining the unity of the unit, Malachi 2:11-16, the prophet dealt with the distinctive aspect of Malachi 2:11-12 and 2:13-16 separately since not all who were guilty of abandoning their wives were doing so for the purpose of intermarriage and not all who were intermarrying had to abandon their wives to do so. It was, however, the problem of divorce with which Malachi was particularly concerned (Clendenen 2004:342).

Ezra and Nehemiah faced problems similar to those confronted by Malachi:

(with the exception of the Sabbath), such as a lack of tithing (Neh 10:32-39; 13:10-13), mixed marriages (Mal 2:10f..; Ezra 9:1f., 10:1f; Neh 13:1-3, 23-27), and the oppression of the poor (Mal 3:5; Neh 5:1-5). (Wickham 2009:17)

However, the problem of:

mixed marriages must not be assumed to be equal in Neh 13 [Ezra 9-10] and Mal 2:10-16. Malachi addresses people who are divorcing their [Jewish] wives, presumably in order to marry younger, foreign wives. However, Nehemiah addresses people who are marrying their children to foreign wives (Neh13:23-28). There is no divorce involved in such actions since they are marrying for the first time. In this sense, the accusation

17.Stuart (1998:1334) believes that 'this phrase as a reference to pagan influences in post-exilic Israelite worship [community]. He contends that the notion of appeasing god in order to gain his favour, regardless of what crimes or sins the worsher human offerings and thus owed the worshipper some benefits. The god would overlook any immorality of ethical misbehaviour and grant forgiveness or blessing on the offerer. Admittedly, this departs drastically from the biblical teaching o offerings. For Israel, worship, offerings and anything related to the cult was "an obligation of gratitude to God, not a means of controlling God's behaviour (Amos 5:21-27; Mic 6:6-8, Mal 2:13)"' (Wickham 2009:148).

18. In his study, Zehnder (2003:224-259) argued that the main thrust of Malachi 2:1316 is against those men within the Yahweh-congregation in Yehud, who expel their first, 'Israelite', wives in order to marry women of a foreign religion. In the context of a fresh interpretation of the passage, a reinterpretation of the textually difficult verse 15 a is offered. As it stands, the MT is most adequately rendered by: 'And no one who has acted that way has a remnant of spirit.' With slight emendations, however, the text can be reconstructed as referring to God's creation of man and dispute in which Malachi is engaged, providing an additional argument against the dissolution of marriage. Though verse 16 a does not contain a general prohibition dissolution of marriage. Though verse 16 a does not contain a general prohibition
of divorce, the reconstructed text of verse 15 a should be understood as a general of divorce, the reconstructed text of verse 15a should be understood as
argument for the indissolubility of marriage' (Zehnder 2003:224-259). was rather different than the one in Malachi (Mal 2:10f.). (Wickham 2009:18)

Ezra addressed Jews - people of Israel, the priests and the Levites - concerning the many marriages that had been concluded with foreign wives and the subsequent divorce of such women. The independent character of Malachi's attack against divorcing Jewish wives in order to marry foreign women (Ml 2:10-16) suggests a date of composition prior to that of the work of Ezra (Ezr 9:2; 10:3, 16-44). This earlier date is made still more likely if the reproach against mixed marriages in Malachi 2:11b is a later insertion, one which precisely reflects the preoccupations of the time of Ezra and Nehemiah (Stuart 1998:1253). ${ }^{19}$

In verse 13, the Qal imperfect ta 'ăśû from 'āśa $\bar{a}^{h}$ means 'you do' or 'you are doing' and conveys the idea of an on-going, progressive action (Brown et al. 1997:793; Harris et al. 1980:1708). This conjugation may thus indicate an ongoing iterative situation and may well be translated thus: 'and another thing that is taking place constantly and repeatedly among you' (w'zō'th shēnith ta 'ăŝu) (Zehnder 2003:231). The entire scenario seems to refer to a situation of lament: the addressees are caricatured by Malachi as flooding Yahweh's altar with tears, weeping $\left(b^{e} k h \hat{\imath}\right)$ and groaning ('ănāq $\left.\bar{a}^{h}\right)$ because Yahweh has rejected their offering (Weyde 2000:252; O'Brien 1990:72). The Piel infinitive construct kassôth comes from the verb $k \bar{a} s \bar{a}^{h}$ and means 'to cover, flood, drown' (Brown et al. 1997:491; Harris et al. 1980:1008). Here it is used figuratively in conjunction with $\operatorname{dim}^{\prime} \bar{a}^{h}$ [tears] (Brown et al. 1997:199) to describe a notorious crying over the altar of Yahweh. According to O'Brien (1990):

... the weeping and groaning described in 2:13 probably do not reflect ritual mourning ... but rather the response of God's refusal of their offerings ... The people in 2:14a inquire of the reasons of His displeasure, a fact suggesting that their transgression has not yet been named. (p. 71)

As to what weeping (bekhî) and groaning ('ănāq $\left.\bar{a}^{h}\right)$ could refer to, Pohlig (1998) says:

They might refer to syncretistic practices among the Jews, perhaps especially to fertility rites ... They refer to ostentatious lamentation, probably of Jews who wanted God to come to their aid in time of drought, sickness, e.t.c. ... They refer to the sincerity of those who sought God's help and who honestly wondered why it did not come ... They refer to the Jews' realization that their worship and sacrifice had no effect with God ... They refer to the lamenting of the divorced wives in Yahweh's sanctuary. (p. 107)

According to Stuart (1998:1334), Malachi's use of the term 'ănāqa $\bar{a}^{h}$ reveals that temple worship in the middle of the 5 th century BCE 'went far beyond a simple (and acceptable) attitude of contrition. It was pagan worship, emphasizing manipulative mourning and misery (Hos 7:14)':

... the fact that the practice is rejected by Yahweh, when it should be one of the honest and most humble expressions of repentance

19. Historical information with respect to the time of writing the book of Malachi which have constituted research problems and from which defensible positions have emerged in several scholarly debates have also been dealt with in the first author's doctoral thesis, which is still in progress. 
before a compassionate God, tells us that such a practice was evil or wrong in itself. Indeed, what makes better sense is that the offenders of the marriage covenant were influenced by foreign rituals and were using them to appease God for their actions. (Wickham 2009:153)

That is the importance of Malachi 2:13b. Since the connection with presenting offerings fits well with Malachi 2:12 (Hill 1998:237):

as an attempt to appease Yahweh and seek his blessing for disobeying marital laws, the offenders tried their best to show Yahweh how much zeal they had for him. The reason why the worshippers are laying such an emphasis on seeking Yahweh with great zeal and emotion is that they are perfectly aware of the significance of their actions in divorcing Hebrew women in order to marry pagan women. (Wickham 2009:153)

Why should Yahweh honour pagan, manipulative worship? He will not regard ( $p^{e} n \hat{t} t h$ 'el) or accept with favour (welāqahath rätsôn) the people's offerings $\left(m i n h \bar{a}^{h}\right)$. They could not obtain Yahweh's blessing through worship whilst they were still sinning, that is, violating the ancient divine covenant against religious intermarriage and thus the first commandment (Stuart 1998:1335).

The answer to the people's question and complaint as stated earlier is that the men of Judah have betrayed their wives. In verse 14, Yahweh stands as a witness against the people's violation of the covenant. The reference to Yahweh acting as a witness is given at least two interpretations: it indicates that Yahweh is a witness that the addressee is faithful to his wife (Glazier-McDonald 1987:100) whilst others hold that Yahweh is conceived of as acting as a witness to marriage, which in this verse is understood as a covenant ( $b^{e}$ rith) between husband and wife (Mason 1990:248; Verhoef 1987:274). Hugenberger (1994:27-115) systematically and convincingly demonstrates that $b^{e}$ rith [covenant] here in Malachi 2:14 refers to marriage. He draws four significant implications from the fact that marriage was viewed as a covenant between husband and wife formed before the Lord. ${ }^{20}$ The nature of this covenant, which obviously has religious significance (Weyde 2000:254), is defined by the phrases 'ésheth $n^{e}$ 'ûrey $k h \bar{a}$ [the wife of your youth] hăbhert ${ }^{e} k h \bar{a}$ [your companion] and 'essheth berithekhā [your wife by covenant].

This expression 'ésheth $n^{e}$ 'ûrey $k h \bar{a}$ reminds one that marriage in Bible times (and still in some parts of the world) was arranged (Jdg 14:1-10). Sometimes before the birth of children, their parents would make arrangement with parents of appropriate mate in anticipation of the time when the two would get married. Prior to the marriage, they were betrothed indicating a legal status. Upon marriage, contracted probably in writing, solemnised by vows, witnessed by

20.These implications are: (1) if a covenant existed between a husband and his wife, any offence against the marriage by either the husband or the wife may be ine, any offence against the marriage by either the husband or the wife may be identified as sin ..., peridy .., or infidelity ... against the other (2) if a covenant existed between a husband and his wife, because God is invoked in any covenantre the husband or the wife may be identified as $\sin . .$. against God (3) ... any marita infidelity ought to prompt God's judgement against the offending party ... (4) ... intermarriage with pagans ought to be prohibited ... (Hugenberger 1994:282-294). ceremony and celebration, and enforced as a covenant by God himself, they certainly were obligated to one another (Stuart 1998:1338). In this regard, the translation of 'èsheth $n^{e} \hat{\text { 'urrey }} \mathrm{kh} \bar{a}$ as 'your childhood wife' would make sense here. Men could marry other wives later, but these wives could never be called 'ésheth $n^{e}$ ' $\hat{u} r e^{y} k h \bar{a}$. Marrying a second wife was never an excuse for divorcing a first one. Thus a man's first wife, 'ésheth $n^{e}$ 'ûrey $k h \bar{a}$, was his wife under God's law, and to break the marriage covenant was to be bāghadh [unfaithful, treacherous or faithless] to one's hăbhēr $\bar{a}^{h}$ [companion] (Stuart 1998:1338).

Malachi uses hăbhert ${ }^{e} k h \bar{a}$ [your companion] and 'ēsheth $b^{e}$ rîthekhā [your wife by covenant] appositionally, as essentially synonymous terms. Since Judah's behaviour was an insult and outrage against Yahweh before whom they have formed their covenants, they were being challenged, warned and indeed threatened that they had not the slightest right to divorce their covenant partner. These men's treatment of their wives was another act by which Judah was profaning Yahweh, like the insulting offerings described in Malachi 1:6-9 (Clendenen 2004:349).

The noteworthy thing about the last two verses of this oracle in Malachi 2:10-16 (vv. 15-16) is the fact that they both end with the language associated with an ultimatum: $w^{e}$ nishmartem berûhăkhem [be on guard for your life]. It cautions the people not to be unfaithful (bāghadh) (O'Brien 1990:73). Malachi calls for faithfulness between husbands and wives because, as Jews, they all had one father, namely Yahweh; because marriage is rooted in the covenant between the husband and wife and because Yahweh intended for a man and his wife to be one flesh ('ehādh 'āśa $\bar{a}^{h} \hat{u} s h^{e} ' \bar{a} r r \hat{u}^{a} h$ ) for the benefit of a godly offspring ( $m^{e}$ bhaqqēsh zera' 'élōhîm). Thus and as a conclusion, if a man and woman form a unity in their marital relationship that is established in creation itself, 'this unity and consequently the marriage covenant is not to be dissolved either by taking another woman in addition to the first one or by divorce' (Zehnder 2003:259). For Malachi, marriage with foreign women, infidelity and divorce were, above all, violations of the fundamental covenant relationship of the Judean community.

\section{Ethical proposals for faith communities}

The significance of this oracle for one's ethical understanding of the Old Testament is that one must take into account the fact that "so much of ... [its] ethical thrust is necessarily social." It's concern is not just to enable "the individual to lead a privately upright life before God" (though this is important), but to promote and protect' (Clendenen 2003:8), as Wright (1983) says:

... the moral and spiritual health of that whole community ... who in their social life would embody those qualities of righteousness, peace, justice and love which reflect God's own character and were his original purpose for mankind. (p. 34)

What moral demand does Malachi's prophetic narrative make at this point upon personal Christian ethics in the 
individual's own course of life and in his or her daily living and the Christian community in the larger human society? What should be the substance and quality of their moral behaviour in response to Yahweh's revelation of himself? The following reflections represent ethical ideals and practical moral demands on Yahweh's people living in human society.

\section{Fidelity and commitment to family values}

Whilst Malachi is a relatively short book, it makes a great deal of ethical contributions to biblical revelation. In his narrative one sees the mutual relationship between lived reality and true faith. In Malachi's day, it was indeed a situation in which the Judeans could not understand their relationship to God and his role in their lives. They were at a crossroad of seeking relevance. Wells (1987) notes that:

The Jews were exchanging God's pattern for life for pleasure, or convenience, or economic considerations. It could be a profound danger for our world-that we may forsake the joy and beauty of lifelong commitment, growing fellowship, the traditions of home and family, for the dubious thrills of cheap pleasures and greener pastures. (p. 54)

Today, we live in a community and society filled with many costly assumptions that marriage and divorce are private matters of the persons' concerned (Schuller 1996:866). This has given room to negligence on the part of some who feel that God is unconnected with their lives. 'God is still relevant! Disaster follows the relegation of God to the periphery of life' (Wells 1987:44).

The crisis involving marriage and the family is indeed a cultural crisis of the first order. Social life quite simply may not function effectively without the family. Wells (1987) carefully describes the home as the centre of human and societal development:

The home was (and is) the center of human development. The family serves to regulate sexual activity. The sexual drive demands careful regulation, else a society is thrown into indiscriminate sexual activity, high incidences of illegitimate birth, and dehumanization of women as sexual objects. Every culture recognizes the need to sanction the sexual life of its members and assure responsible parents for its children. The family serves as the agency of reproduction ... Families are thus crucial to the very survival of the race. The family socializes the members of a culture. The family transmits to its children the goals, values, norms, obligations, expectations, rules, rights, and so on, which characterize life in a given society. The family provides the most basic and primary form of companionship and love, which are needed by all persons. Ideally, husband, wife and children all find their love needs met in the family circle. The family gives the members of society their identity. Religious, social, ethnic, and national identity is conferred, first of all, in and by the family. (pp. 51-52)

Marriage can be marvellous; it can also be miserable. The differences and the uncertainties that marriage creates frequently receive a lot of negative attention in the press. Today:

marriage has suffered at the hands of the prevailing cultural view. The Israelite may have sought an exciting foreign wife, or maybe just a wife who could have children. A contemporary American [or African] (maybe a Christian) might be seeking a happy relationship. But in either case, marriage degenerates into a convenience. (Wells 1987:53)

Malachi's prophetic oracle is an urgent motivation and challenge to Yahweh's people in communities of faith and society in general to be a living embodiment of the ideals of fidelity, commitment and steadfastness.

Since human dignity is based on the belief that we were all created in the image of God (Flowers \& Flowers 2001):

Christians are called to treat people and families everywhere with respect and integrity, and to uphold and strengthen that which is good and in keeping with biblical principles in their family and cultural heritage. At the same time, families-and the cultures of which they are a part—can only mirror the fallen apart of the people who comprise them. Thus Christian families are called to allow the overarching principles of Scripture to reshape their patterns of relating and their traditions in pursuit of God's original design for human relationships. (p. 1)

Christians should understand and appreciate the fact that children are God's heritage and godly children are upshot of healthy, viable and godly marriages. The health of the family itself is dependent on the vitality of marital bond. It is therefore useless to emphasis raising good, robust and sustainable families apart from healthy marriages (Wells 1987:53).

What a wonderful challenge Malachi is to all couples in faith communities and society (religious or not), to, as Bryan (2001) says:

... take seriously their marital relationship - to give it time and energy, to revitalise their love for each other, and to accept responsibility for their relationship. Through God's grace a couple can empower and revitalise their relationship. By developing a positive, supportive atmosphere in their relationship, they make it safe to be with each other. Thus when they affirm and build each other up, when they show unconditional acceptance and love for each other, when they are assertive and honestly communicate with each other, when they recognise and validate each other's feelings and take responsibility for their relationship, they build, by the grace of God, a relationship that is healthy, viable, fulfilling and long lasting. (p. 8)

\section{Empowering families for growth and change}

Since Malachi consistently roots his narrative of marriage within the framework of a community that shares an essential relationship and fellowship based on a common father and creator, the larger community obviously has a stake in the individual's marriage partner, the maintenance of fidelity to the marriage bond and in what happens when the bond is sundered in divorce. Infidelity, the failure of a marriage and divorce are essentially concrete and visible manifestations of a breakdown in the ideals. The larger community is rightly concerned with the emotions and needs, the freedom and the value of the individual. In honouring the values and 
ideals of fidelity, commitment and steadfastness, Yahweh's faith communities are challenged to seek concrete ways of affirming, strengthening, empowering and supporting persons and families in their efforts to live in faithfulness to the values they recognise and esteem (Schuller 1996:866).

The text (Malachi 2:10) does not in any way advocate the practice of polygamy but endorse the monogamous ideal for actual marital relationship and practice. This has been God's order or plan for every Christian marriage. Similarly, whilst it illustrates the many divorces that were taking place at this time, it says nothing to suggest that divorces are criminal, but denounces divorce on account of its ethical implications, an illustration of unfaithfulness or infringement of covenant which is prone to divine judgement. A marriage that endures for life is one that is well integrated with webs of relationship. It is a marriage covenanted in order to enrich relationships and integration within the family, home and society. The marriage covenant is that which rest on vital principles, as Flowers and Flowers (2001) point out:

... love, loyalty, exclusivity, trust and support upheld by both partners (Gen. 2:24; cf. 1 Cor. 13; Eph. 5:21-29; 1 Thess. 4:1-7). When these principles are violated through abuse, abandonment or other instances of unfaithfulness to the marriage vow, the essence of the marriage covenant is endangered. (p. 86)

Malachi's prophetic narrative is a call to Yahweh's faith communities (the church) in all ages to an engagement in family ministries. In their understanding Flowers and Flowers (2001) note:

Family Ministries is a ministry of grace which acknowledges as normative the biblical teachings relating to the family and holds high God's ideals for family living. At the same time, it brings an understanding of the brokenness experienced by individuals and families in a fallen world. Thus Family Ministries seeks to enable families to stretch toward divine ideals, while at the same time extending the good news of God's saving grace and the promise of growth possible through the indwelling Spirit ... Family ministry helps the church to take a fresh look at Scripture, to put on what we might call 'family glasses' and to see in the word of God its profound teachings about family relationships. (p. 78)

Thus the church, through her organ of education is challenged to teach:

- The realities of change and adjustment following emigration of a family.

- Impact of financial reverses on families.

- Family crises, including grief and loss recovery following the deaths of family members.

- Spiritual issues, crises of faith resulting from significant losses ...

- Adoption of local cultural values by offspring.

- In-law relationships.

- The personal experience of low self-worth; how self-worth can be encouraged.

- Effect of temperament and personality differences on family coping skills.

- Cultural influences on marriage and family patterns.

- The evangelistic and pastoral impact of a ministry of caring and acceptance.

- The transforming effects of the gospel on the well-being of a family. (Flowers \& Flowers 2001:80)

\section{Conclusion}

In this article, we have demonstrated that Malachi's third oracle is addressed to the greater restoration community of Yehud - leaders, priests and people, the 'one' people of Yahweh. The purpose of this oracle is didactic, that is, to provide correct instruction on the topics of marriage and divorce. Malachi consistently roots his narrative of marriage within the framework of a community that shares an essential relationship and fellowship based on a common father and creator. The ethical dimension of the oracle reveals malpractices concerning mixed marriages and unfaithfulness to God (Ml 2:10b-12) and the heartless divorce of Judean wives by Judean men (2:13-16). These indeed are supercilious and reprehensible misdeeds before Yahweh, an affront to the essence of covenant relationship socially and religiously. For Malachi, marriage with foreign women, infidelity and divorce were, above all, violations of the fundamental covenant relationship of the Judean community. The ethical concern of this oracle 'is not just to enable "the individual to lead a privately upright life before God" ... but to promote and protect "the moral and spiritual health of that whole community"' (Clendenen 2003:8).

The article reflects concern on the home as the centre of human and societal development. Thus in order to build healthy and viable families where the joy and beauty of lifelong commitment, growing fellowship, the traditions of home and family are celebrated, individuals are challenged to embody those qualities of fidelity, commitment and steadfastness. Since marriage can be marvellous and can also be miserable, faith communities are challenged to seek concrete ways of affirming, strengthening, empowering and supporting persons and families in their efforts to live in faithfulness to the values they recognise and esteem. These ethical proposals will help to a greater extent in building healthy and viable families.

\section{Acknowledgements Competing interests}

The authors declare that they have no financial or personal relationships that may have inappropriately influenced them in writing this article.

\section{Authors' contributions}

The article is based on research conducted by B.O.B. (University of Pretoria) for his PhD thesis. A.G. (University of Pretoria), co-author of the article, acted as supervisor for the thesis.

\section{References}

Assis, E., 2011, 'Moses, Elijah and the messianic hope: A new reading of Malachi 3 22-24', Zeitschrift fur die Alttestamentliche Wissenschaft 123(2), 207-220. http:// dx.doi.org/10.1515/zaw.2011.013

Barton, J., 1995, 'Ethics in Isaiah of Jerusalem', in R.P. Gordon (ed.), The place is too small for us: The Israelite prophets in recent scholarship, pp. 80-97, Eisenbrauns, Winona Lake. (Sources for Biblical and Theological Study 5). 
Block, D.I., 2006, 'Preaching Old Testament apocalyptic to a New Testament church', Calvin Theological Journal 3(2), 17-52.

Boda, M.J., 2000, 'Haggai: Master rhetorician', Tyndale Bulletin 51(2), 295-304.

Botterweck, G.J. \& Ringgren, H. (eds.), 1974, Theological dictionary of the Old Testament, transl. J.T. Willis, G.W. Bromiley \& D.E. Green, 15 vols, Eerdmans, Grand Rapids.

Braun, R., 1977, 'Malachi: A catechism for times of disappointment', Currents in Theology and Mission 4, 297-303.

Brown, F., Diver, R.S. \& Briggs, C.A. (eds.), 1997, Hebrew and English lexicon of the Old Testament $(B D B)$, Hendrickson Publishers, Peabody.

Bryan, C., 2001, 'Making your marriage work!', Families of faith: Biblical foundations for family living, 1-8, viewed 13 March 2013, from http://familyministries. gc.adventist.org

Carroll, R., 2012, 'Ethics', in M.J. Boda \& J.G. McConville (eds.), Dictionary of the Old Testament Prophets, pp. 185-193, Inter-Varsity Press, Downers Grove.

Childs, B.S., 1979, Introduction to the Old Testament as scripture, Fortress Press, Philadelphia.

Chisholm, R.B., 2002, 'A theology of the minor prophets', in R.B. Zuch (ed.), Biblical Theology of the Old Testament, pp. 397-433, Moody Press, Chicago.

Clendenen, E.R., 2003, C. J. H. Wright's 'Ethical Triangle' and the Threefold Structure of Malachi, Broadman and Holman Publishers, Nashville.

Clendenen, E.R., 2004, 'Malachi', in E.R. Clendenen \& R.A. Taylor (eds.), Haggai, Malachi, n.p., Broadman and Holman Publishers, Nashville. (New American commentary, 21A)

Craig, K.M. Jnr., 1996, 'Interrogatives in Haggai-Zechariah: A literary thread?', in P.R. House \& J.W. Watts (eds.), Forming prophetic literature: Essays on Isaiah and the Twelve in honor of John D.W. Watts, pp. 224-244, Sheffield Academic Press, Sheffield.

Dumbrell, W.J., 1976, 'Malachi and the Ezra-Nehemiah reforms', Reformed Theological Review 35, 42-52.

Flowers, K. \& Flowers, R., 2001, 'Biblical foundations of family ministries', Families of faith: Biblical foundations for family living, 78-96, viewed 14 March 2013, from http://familyministries.gc.adventist.org

Floyd, M.H., 2000, Minor prophets: Part 2, Eerdmans, Grand Rapids. (The forms of the Old Testament literature, vol. 22).

Glazier-McDonald, B., 1987, Malachi the divine messenger, Scholars Press, Atlanta. (Society of Biblical Literature Dissertation Series, 98).

Groenewald, A., 2009, 'Ethics of the Psalms: Psalm 16 within the context of Psalms 15-24', Journal for Semitics 18(2), 421-433.

Groenewald, A., 2011, 'Isaiah 1:2-3, ethics and wisdom. Isaiah 1:2-3 and the Song of Moses (Dt 32): Is Isaiah a prophet like Moses?', HTS Teologiese Studies/Theological Studies 67(1), Art. \#954, 6 pages. http://dx.doi.org/10.4102/hts.v67i1.954

Hendrix, J.D., 1987, 'You say: Confrontation dialogue in Malachi', Review and Expositor 30, 465-477.

Harris, R.L., Archer, G.L. \& Waltke, B.K. (eds.), 1980, Theological wordbook of the Old Testament (TWOT), 2 vols., Moody Press, Chicago.

Hill, A.E., 1998, Malachi: A new translation with introduction and commentary, Anchor Bible, Doubleday.

Hugenberger, G.P., 1994, Marriage as a covenant: Biblical law and ethics governing marriage developed from the perspective of Malachi, Brill, Leiden. (Vetus Testamentum Supplement 52).

Jackson, J., 2004, 'Abigail or Asherah: Competing canonical readings of Malachi 2.1216', Leaven 12(1), 40-48. http://digitalcommons.pepperdine.edu/leaven/vol12/ iss $1 / 8$

Jensen, J., 2006, Ethical dimensions of the prophets, Liturgical Press, Collegeville.

Kealy, S.P., 2009, An interpretation of the twelve minor prophets of the Hebrew Bible: The emergence of eschatology as a theological theme, The Edwin Mellen Press, Lewiston. PMCid:PMC2672799
Lemergen

Koorevaar, H.J., 2010, 'The Torah model as original macrostructure of the Hebrew canon: A critical evaluation', Zeitschrift fur die Alttestamentliche Wissenschaft 122(1), 64-80. http://dx.doi.org/10.1515/zaw.2010.006

Levin, C., 2006, Das Alte Testament, C.H. Beck, München.

Mason, R., 1990, Preaching the tradition: Homily and hermeneutics after the exile, Cambridge University, Cambridge. http://dx.doi.org/10.1017/ CB09780511470462
Merrill, E.H., 1994, Haggai, Zechariah and Malachi: An exegetical commentary, Moody Press, Chicago.

Murray, D.F., 1987, 'The rhetoric of disputation: Re-examination of a prophetic genre', Journal for the Study of Old Testament 38, 95-121. http://dx.doi. org/10.1177/030908928701203808

Nogalski, J.D., 2011, The book of the twelve: Micah-Malachi, Smyth \& Helwys Publishing, Inc., Macon. PMid:21084488, PMCid:PMC3020497

O'Brien, J.M., 1990, Priest and levite in Malachi, Scholars, Atlanta. (Society of biblical literature dissertation series, 121).

O'Brien, J.M., 1995, 'Historical criticism as liberator and master: Malachi as a postexilic document', in J.M. O'Brien \& F.L. Horton, Jnr. (eds.), The Yahweh/Baa confrontation and other studies in biblical literature and archaeology: Essays in honor of Emmett Willard Hamrick, pp. 57-79, Mellen Biblical Press, Macon. (Studies in Bible and Early Christianity, 35).

O'Brien, J.M., 1996, 'Judah as wife and husband: Deconstructing gender in Malachi', Journal of Biblical Literature 115(2), 241-250. http://dx.doi.org/10.2307/3266854

O'Keefe, J.J., 1996, 'Christianizing Malachi: Fifth-century insights from Cyril of Alexandria', Vigiliae Christianae 50(2), 136-158. http://dx.doi. org/10.1163/157007296x00049

Otto, E., 1995, 'Of aims and methods in Hebrew Bible ethics', Semeia 66,161-172.

Otto, E., 2004, 'Law and ethics', in S.I. Johnson (ed.), Religions of the ancient world: A guide, pp. 84-97, Harvard University Press, Cambridge. PMid:15528296

Otto, E., 2007, 'Myth and Hebrew ethics in the Psalms', in D.J. Human (ed.), Psalms and mythology, pp. 26-37, T\&T Clark, London. (Library of the Hebrew Bible/Old Bible studies, 462)

Petersen, D.L., 1995, Zechariah 9-14 and Malachi, SCM Press Ltd., London. (Old Testament Library).

Pierce, R.W., 1984, 'Literary connectors and a Haggai/Zechariah/Malachi corpus', Journal of the Evangelical Theological Society 27, 277-289.

Pohlig, J.N., 1998, An exegetical summary of Malachi, Summer Institute of Linguistics Inc., Dallas.

Redditt, P.L., 2000, 'Book of Malachi', in W. Elwell (ed.), Eerdmans Dictionary of the Bible, vol. 3, pp. 848-849, Baker, Grand Rapids.

Schuller, E.M., 1996, 'The book of Malachi', in L.E. Keck \& D. Peterson (eds.), The new interpreter's Bible, pp. 843-877, Abingdon Press, Nashville.

Smith, R.L., 1984, Micah - Malachi, Word Books, Waco. (Word Biblical commentary, 32).

Stuart, D., 1998, 'Malachi', in T.E. McComiskey (ed.), The minor prophets: An exegetical and expository commentary, vol. 3, pp. 1245-1396, Baker Books, Grand Rapids.

Tiemeyer, L.S., 2006, Priestly rites and prophetic rage: Post-exilic prophetic critique of the priesthood, Mohr Siebeck, Tubingen. (Forschungen zum Alten Testament, 19).

Van der Woude, A.S., 1986, 'Malachi's struggle for a pure community: Reflections on Malachi 2:10-16', in J.C.H. Lebram \& W. van Henten (eds.), Tradition and reinterpretation in Jewish and early Christian literature. Essays in honour of J.C.H Lebram, pp. 65-71, Brill, Leiden. (Studia post-biblica, 36).

Verhoef, P.A., 1987, The books of Haggai and Malachi, Eerdmans, Grand Rapids. (New international commentary on the Old Testament, series editors R.K. Harrison \& international comm
R.L. Hubbard Jr.).

Walter, J.H., 2007, 'The character of YHWH and the ethics of the Old Testament: Is Imitatio Dei appropriate?', Journal of Theological Studies 58(1), 1-25.

Wells, R.C., 1987, 'The subtle crises of secularism: Preaching the burden of Israel', Creswell Theological Review 2(1), 39-61.

Weyde, K.W., 2000, Prophecy and teaching: Prophetic authority, form problems, and the use of traditions in the book of Malachi, Walter de Gruyden, Berlin. $\mathrm{http} / / / \mathrm{dx}$.doi.org/10.1515/9783110811780 (Beihefte zur Zeitschrift fur die Alttestamentliche Wissenschaft, 288)

Wickham, A.D., 2009, 'The offering aspect of Israel's cultic observance in the book of Malachi', M.Th. dissertation, Dept. of Old Testament, University of South Africa.

Wright, C.J.H., 1983, Living as the people of God: The relevance of Old Testament ethics, Inter-Varsity Press, Leicester.

Wright, C.J.H., 2004, Old Testament ethics for the people of God, Inter-Varsity Press, Leicester.

Zehnder, M., 2003, 'A fresh look at Malachi II 13-16', Vetus Testamentum LIII(2), 224-259. 